\title{
Multiple renal abscesses leading to nephrectomy of the solitary kidney in a young female with type 1 diabetes and history of recurrent urinary tract infections
}

Zofia Wańkowicz'1, Anna Grzywacz', Marek Saracynn', Henryk Zieliński²

\author{
${ }^{1}$ Department of Internal Diseases, Nephrology and Dialysis, Military Institute of Health \\ Service, Warsaw, Poland \\ 2Department of Urology, Military Institute of Health Service, Warsaw, Poland
}

Submitted: 5 November 2009

Accepted: 25 December 2009

Arch Med Sci 2011; 7, 2: 349-352

DOI: 10.5114/aoms.2011.22091

Copyright @ 2011 Termedia \& Banach

\author{
Corresponding author: \\ Anna Grzywacz MD, \\ Department of Internal \\ Diseases \\ Nephrology and Dialysis \\ Military Institute \\ of Health Service \\ 128 Szaserów \\ 04-141 Warsaw, Poland \\ E-mail: \\ anna.m.grzywacz@gmail.com
}

\begin{abstract}
This report presents the case of a young female suffered for many years from type 1 diabetes, complicated by recurrent urinary tract infections and urosepsis with multiple abscesses which led to right nephrectomy in 2002. The patient was hospitalised in our Department in June 2009 because of urosepsis in the course of multiple left renal abscesses and subsequent acute renal failure requiring hemodialysis. A dramatic decision of removing the solitary kidney was taken, and patient was included in a long-term renal replacement therapy programme in our Centre as a preparation to kidney and pancreas transplantation.
\end{abstract}

Key words: urinary tract infections, renal abscesses, nephrectomy.

\section{Introduction}

Urinary tract infections (UTIS) are usually caused by the Enterobacteriaceae family, mainly Escherichia coli, and most often they involve the lower part of the urinary tract. However, in some cases, they manifest as interstitial nephritis, also known as pyelonephritis. The incidence of UTIs is higher in females than in males, particularly in the 16-35 age group where they occur 40 times more frequently in women than in men at a comparable age. The risk factors for UTIs in females include short urethra, small distance between urethra and anus, vaginal colonisation by bowel microflora, sexual activity, use of vaginal contraceptives, disturbed vaginal ecosystem, e.g. owing to previous antibiotic therapy, a history of recurrent UTIs and the first episode before the age of 12-15. The occurrence of mother's history of UTIs indicates that a genetic predisposition might be important in some cases [1].

Female diabetic patients are particularly prone to asymptomatic bacteriuria and UTI. Aetiological factors in this group are the same as in non-diabetic patients, but the sensitivity of these strains to standard antibiotics is lower [2]. What is more, diabetes increases the risk of UTI complications, such as intrarenal abscess, renal corticomedullary abscess, multiple renal abscesses, emphysematous pyelonephritis or kidney papillary necrosis. If in the course of UTI body temperature rises above $39^{\circ} \mathrm{C}$, chills and costovertebral angle tenderness are observed, and the above 
symptoms do not regress despite appropriate treatment, urinary tract radiographic imaging examination should be performed promptly in order to exclude the above-mentioned complications [3].

The aim of this report was to present a case of complicated UTI accompanied by multiple left renal abscesses in a patient with type 1 diabetes. The dramatic course of the disease led to nephrectomy of the only kidney and the initiation of renal replacement therapy.

\section{Case report}

A 28-year-old Caucasian woman with type 1 diabetes complicated with polyneuropathy, proliferative retinopathy and bilateral maculopathy was admitted to our department on 16 June 2009 in a severe general condition, with oliguria, consciousness disturbances, skin hyperesthesia and body temperature up to $38.5^{\circ} \mathrm{C}$ with chills. Physical examination revealed strongly positive left Goldflam's sign, hypotension, oliguria and small peripheral oedema. In laboratory tests, of interest were microcytic anaemia (haemoglobin: $7.6 \mathrm{~g} / \mathrm{dl}$, MCV: $75 \mathrm{fl})$, leucopenia $(3000 / \mu \mathrm{l})$, and biochemical signs of renal failure (serum creatinine and urea levels of $7.3 \mathrm{mg} / \mathrm{dl}$ and $280 \mathrm{mg} / \mathrm{dl}$, respectively; normal potassium level). On abdominal ultrasound examination (US), the absence of right kidney and left kidney enlargement with features of interstitial oedema and kidney papillary oedema were found.

In anamnesis the patient had been suffering from diabetes since the age of 11 , remaining under diabetic care of a local outpatient department. During the 17 years of observation, numerous recurrences of UTIs had been noted, complicated in 2002 by septic shock in the course of multiple right renal abscesses, revealed in computed tomography (CT) and a histopathological examination of the removed kidney. In the years 2005-2008, the patient had been hospitalised 3 times because of urosepsis; in addition, pyelonephritis episodes had been occurring 3-4 times a year. Before admission to our clinic there was no evidence of nephrologist consultation or medical documentation of full diagnostic imaging examination of risk factors for complicated UTI. Moreover, no data on long-term prophylaxis of recurrent UTIs, recommended as a standard procedure in such cases, were found [2]. The clinical picture of the disease further revealed that the UTIs had been, from the beginning, combined with involvement of the upper urinary tract with no dysuric symptoms preceding these episodes.

Three weeks prior to admission to our department, the patient had been hospitalised in a diabetes ward in another hospital in order to modify her diabetes treatment. Considering the presence of UTI symptoms such as fever, significant bacteriuria and leukocyturia, and positive urine culture (E. coli at $10^{5} \mathrm{cfu} / \mu \mathrm{l}$, with broad sensitivity), short-term oral antibiotic therapy in accordance with the antibiogram was administered. Regression of symptoms was achieved, although no control urinalysis had been performed. During this hospitalisation, biochemical signs of renal failure were found (serum creatinine, urea and potassium of $1.5 \mathrm{mg} / \mathrm{dl}, 59 \mathrm{mg} / \mathrm{dl}$ and $5.9 \mathrm{mmol} / \mathrm{l}$, respectively). Estimated glomerular filtration rate (eGFR), calculated based on the MDRD formula, was $44 \mathrm{ml} / \mathrm{min} / 173 \mathrm{~m}^{2}$. Upon discharging the patient to the outpatient department, nitrofurantoin at single night-time doses for 14 days and Uro-Vaxom vaccine were recommended. Already one week after leaving the hospital, the patient's general condition deteriorated, with the occurrence of syncope, hypotension, vomiting and oliguria. The nitrogen retention parameters were elevated as well (creatinine: $5.3 \mathrm{mg} / \mathrm{dl}$, urea: $183 \mathrm{mg} / \mathrm{dl}$ ). The patient was referred to our department as an emergency case due to acute renal failure.

Having obtained access to the central vein, haemodialysis treatment was initiated immediately. In view of the clinical signs of urosepsis, once the urine and blood samples were collected for cultures, intravenous broad-spectrum antibiotic therapy was started (cefotaxime + ciprofloxacin) at full therapeutic doses. Despite such treatment, pain in the costovertebral angle was more intense, significant bacteriuria and leukocyturia persisted, levels of inflammatory markers increased (C-reactive protein and leucocytosis up to $27.8 \mathrm{mg} / \mathrm{dl}$ and $21500 / \mu$ respectively), and the fever (up to $38.5^{\circ} \mathrm{C}$ ) with chills remained. Therefore, an abdominal CT scan was performed. It revealed the presence of numerous low-density fluid collections throughout the whole kidney, most likely representing purulent lesions, as well as free fluid in the pleural and peritoneal cavities (Figure 1). There was no distension of the collecting system.

During the following days, the antibiotic therapy was modified and amikacin was included with cefotaxime instead of ciprofloxacin, along with metronidazole, at standard therapeutic doses. In view of the dramatic deterioration of the patient's general condition, lack of efficacy of the broadspectrum antibiotic therapy, as well as clear signs of presence of multiple abscesses on $\mathrm{CT}$, the patient and her family were informed, by the consultant from the Urology Department, about the necessity of immediate nephrectomy, and at the same time assured of the availability of subsequent renal replacement therapy in our clinic. The patient and her family agreed to our proposition.

On 23 June nephrectomy of the solitary left kidney was performed at the Urology Department. On the intraoperative examination, presence of 
multiple abscesses was confirmed. The microscopic findings were as follows: nephritis purulenta partim abscendens cum perinephritide purulenta consecutiva, pyelitis chronica exacerbata, infiltratio inflammatoria purulenta et abscendens hili renis. Lymphonodulitis reactiva cum histiocytosi sinusali.

During the patient's stay at the Urology Department, intravenous broad-spectrum antibiotic therapy with cefotaxime, amikacin and metronidazole was continued, while a long-term haemodialysis regimen consisting of 4-h sessions 3 times a week was initiated. Ten days after nephrectomy, the patient was discharged from the hospital in a good general and local condition, continuing haemodialysis treatment in an outpatient setting.

One month after initiation of the haemodialysis programme, the patient expressed her willingness to find out about our peritoneal dialysis educational programme. Subsequently, together with her family, she decided to participate in this programme, which, in her complex professional and family situation, provides a better quality of life in comparison with haemodialysis.

\section{Discussion}

The patient presented in this report is the second case in the history of our department of recurrent UTIs in a young female, with periodical urosepsis or even septic shock, in the course of multiple bilateral renal abscesses. In both cases, a dramatic decision of radical nephrectomy, as a lifesaving procedure, followed by initiation of renal replacement therapy had to be taken [4].

While discussing the case described here, we would like to emphasize several aspects that appear to be of particular significance. Firstly, in view of the recurrent nature (3-4 episodes a year) of UTIs with clinically severe course, appropriate prophylactic treatment should have been initiated a number of years before. This usually involves chemotherapeutic agents at suppressive doses, taken at night-time, after bladder emptying, for a period of 6-24 months. In cases where the UTI is connected with sexual activity, an additional dose taken after intercourse is recommended. The following active substances are offered: nitrofurantoin 50-100 mg, norfloxacin 200$400 \mathrm{mg}$, co-trimoxazole $80 / 400 \mathrm{mg}$, trimethoprim 100-200 mg, ciprofloxacin $250 \mathrm{mg}$, or cephalexin $250 \mathrm{mg}$. Proven efficacy in UTI prevention has been reported for fresh cranberry fruit at $50 \mathrm{~g}$ daily, cranberry juice at $300 \mathrm{ml}$ or cranberry tablets, as well as acidification of urine with diet or vitamin $\mathrm{C}$ at $1 \mathrm{~g}$ daily, vaginal delivery of lactobacilli and/or oestriol during the perimenopausal period [1]. Moreover, extracts of uropathogenic $E$. coli strains may be beneficial in the prevention of UTI recurrence in

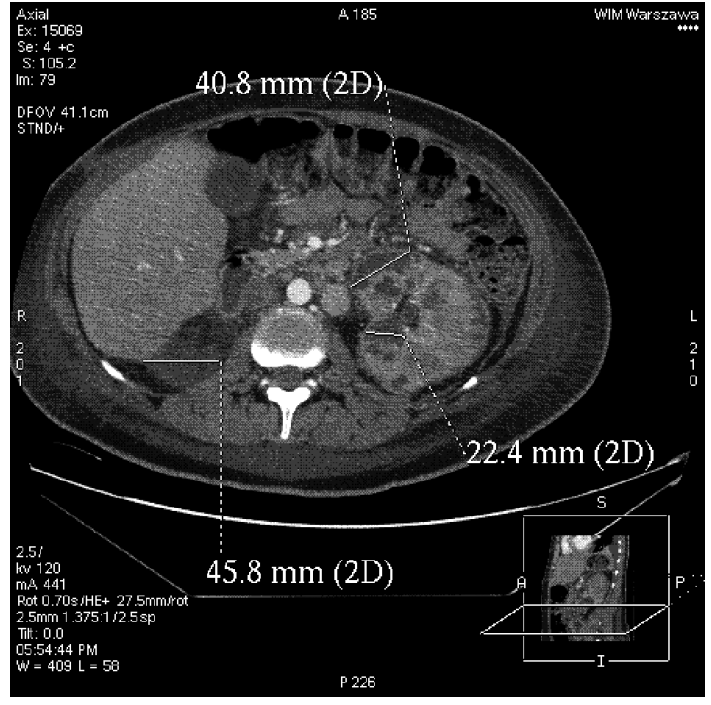

Figure 1. Multiple renal abscesses in the solitary kidney and the free fluid in the peritoneal cavity CT scan

females [5]. Of equal importance is the nonpharmacological approach: proper perineal hygiene, intake of large amounts of liquids, practising so-called double bladder emptying after sexual intercourse, or abandoning the use of spermicides [1]. In terms of pyelonephritis prevention, the experience of our centre, dating back to 1970, indicates the efficacy of long-term suppressive treatment. This involves alternate use, in 2-week cycles, of amoxicillin with clavulanic acid and nitrofurantoin, co-trimoxazole or fluoroquinolone, taken at a single night-time dose, for 6-24 months. During the nitrofurantoin therapy, urine is acidified using an appropriate diet, cranberries or vitamin C. When administering the above chemotherapeutic agents, contraindications against their use should always be taken into account - in the case of nitrofurantoin these include diagnosed polyneuropathy and renal failure with oliguria and anuria [6].

The second important issue is the necessity of performing causal diagnostics in the case of urosepsis, particularly of recurrent nature. In complicated UTIs the US examination and CT scan have the widest application. CT is a more reliable technique in proper evaluation of purulent lesions in kidneys than US imaging [7]. The observed deterioration of the patient's general condition, despite broad-spectrum antibiotic therapy administered for several days, suggested the presence of renal abscesses and prompted the performance of urgent diagnostic imaging of the urinary tract. The US examination did not reveal fluid collections, but the CT scan evidenced the presence of multiple abscesses throughout the whole kidney, which led to the difficult decision of performing a nephrectomy of the only kidney and initiating long-term renal replacement therapy. After 
the procedure, febrile states retreated and the patient's general condition improved.

Another problem to consider is the issue of renal replacement therapy in a diabetic patient after bilateral nephrectomy. For patients suffering from type 1 diabetes, the optimal management method is kidney and pancreas transplantation from a deceased donor. The second-choice approach is kidney transplantation from a living donor, while the next considered option is only kidney transplantation from a deceased donor. In the case of the patient described here, acute renal failure followed by the removal of the only kidney caused the necessity of initiating a haemodialysis regimen. Common problems in diabetic patients on haemodialysis are difficulty in obtaining good vascular access and haemodynamic instability during procedures with frequent intradialysis hypotension episodes.

In view of the above, as well as upon analysing the patient's professional and family situation, a decision was made to initiate a regimen of peritoneal dialysis, as preparatory management before kidney transplantation. The patient's poor visual acuity caused by proliferative diabetic retinopathy may pose some problem. However, there have been cases in the history of our department of completely blind patients who, after being properly trained by our staff, have coped with this method very well [8]. Yet another argument for initiating this type of renal replacement therapy was the patient's caring family, deeply involved in the whole process of her medical treatment. To our knowledge and belief, the decision taken appears correct and justified.

\section{Acknowledgments}

We would like to thank Doctor R. Kidzinski for CT scan preparation

\section{References}

1. Wańkowicz Z. Odrębności zakażeń układu moczowego u kobiet i mężczyzn [Polish]. Pol Arch Med Wewn 2004; 112: 41-55.

2. Pallarés J, López A, Cano A, Fábrega J, Mendive J. La infección urinaria en el diabetic. Aten Primaria 1998; 21: 630-7.

3. Wańkowicz Z. Choroby układu moczowego. In: Brzozowski R. Vademecum lekarza praktyka [Polish]. PZWL, Warszawa 2001; 375-439.

4. Wańkowicz Z, Olszowska A, Stawarz B, Zabuska-Jabłońska K. Obustronna nefrektomia jako zabieg ratujący życie u młodej kobiety z nawracającym wstrząsem bakteriemicznym [Polish]. Pol Arch Med Wewn 2001; 5: 1059-63.

5. Ha US, Cho YH. Immunostimulation with Escherichia coli extract: prevention of recurrent urinary tract infections. Int J Antimicrob Agents 2008; 31 Suppl 1: S63-7.

6. Wańkowicz Z, Kozaczek W, Piotrowska E, Przedlacki J, Król M. Odlegte losy chorych po ostrym odmiednicz- kowym zapaleniu nerek [Polish]. Pol Arch Med Wewn 1970; 45: 793-802.

7. Stojadinović M, Mićić S, Milovanović D. Ultrasonographic and computed tomography findings in renal suppurations: performance indicators and risk for diagnostic failure. Urol Int 2008; 80: 389-97.

8. Wańkowicz Z, Pietrzak B, Durlik M. Przewlekły program dializ otrzewnowych $w$ leczeniu nieodwracalnej niewydolności nerek wikłającej nefropatię cukrzycową [Polish]. Pol Tyg Lek 1993; 20-22: 460. 